\title{
O papel da produção de novidades na agricultura familiar: estudo de caso de um condomínio de grãos no sudoeste do Paraná
}

\author{
Jhuly Caroline Biava ${ }^{11}$ \\ Miguel Angelo Perondi22 \\ Marcio Gazolla ${ }^{33}$
}

\begin{abstract}
Resumo
O objetivo deste trabalho foi o de analisar o surgimento de novidades em torno de uma experiência familiar em um condomínio de grãos na Região Sudoeste do PR, evidenciando seus resultados para os atores sociais envolvidos. Para atingir este objetivo, utilizou-se entrevistas e uma avaliação socioeconômica do sistema de produção num período de 10 anos. Teoricamente, a pesquisa se apoiou na Perspectiva Multinível e CoEvolucionária (PMN), especialmente na noção de novidades no desenvolvimento rural e regional. Com o resultado, evidencia-se que a novidade organizacional do condomínio e seu decorrente processo de trabalho associado entre os familiares gerou aumento da renda familiar e consolidou a sucessão na unidade de produção.
\end{abstract}

Palavras-chave: Agricultura familiar. Condomínio. Novidade organizacional. Sucessão geracional. Desenvolvimento rural e regional.

\begin{abstract}
The objective of this work was to analyze the emergence of novelties around a family experience of a grain condominium in the region Southwest of $P R$, showing its results for the social actors involved. To achieve this goal, it was used of interviews and a socioeconomic evaluation of the production system in a period of 10 years. Theoretically, the research was based on the Multi-Level and Co-Evolutionary Perspective (PMN), especially on the notion of novelties in rural and regional development. From results, it was evident that the organizational novelty of the condominium and its consequent work process associated between the family members generated an increase in family income and consolidated the generation succession on the productions units.
\end{abstract}

Keywords: Family farm. Condominium. Organizational novelty. Generational succession. Regional and rural development.

\section{Introdução}

A produção agropecuária de grãos e commodities ainda é a estratégia predominante de desenvolvimento rural brasileiro, especialmente para a agricultura de grande escala,

\footnotetext{
${ }^{1}$ Engenheira Agrônoma. Universidade Tecnológica Federal do Paraná (UTFPR). biava.jhuly@gmail.com

${ }^{2}$ Doutor em Desenvolvimento Rural. Professor do Programa de Pós-Graduação em Desenvolvimento Regional (PPGDR) da Universidade Tecnológica Federal do Paraná (UTFPR). miguelangeloperondi@gmail.com

${ }^{3}$ Doutor em Desenvolvimento Rural. Professor do Programa de Pós-Graduação em Desenvolvimento Regional (PPGDR) da Universidade Tecnológica Federal do Paraná (UTFPR). marciogazolla1@gmail.com
} 
embora uma parte significativa da agricultura familiar também siga essa mesma trajetória. A produção de grãos no Brasil seguiu o caminho da modernização da agricultura, sendo desenvolvida uma lógica de cientificação e mercantilização crescente dos processos sociais e econômicos (PLOEG, 1992).

No caso da agricultura familiar em pequenas áreas, estudos têm apontado para a inviabilidade técnica, social, econômica e ambiental do desenvolvimento agrícola pautado na produção de grãos e commodities, devido à impossibilidade de acesso e emprego de tecnologias intensivas e caras, os pequenos valores agregados à produção, os mercados incertos e com preços instáveis e os impactos das monoculturas ao meio ambiente (GRAZIANO DA SILVA, 1999; SCHNEIDER; CASSOL, 2014).

É dentro deste contexto em que transcorre a produção de commodities brasileiras, que o trabalho analisa a iniciativa de um condomínio de grãos, na agricultura familiar da Região Sudoeste do Paraná. Trata-se de duas famílias com parentesco direto, que se unem, a partir da safra 2010, para trabalhar, produzir e gerenciar os fatores de produção de forma associada (terras, força de trabalho, máquinas e equipamentos).

O objetivo deste trabalho foi o de analisar o condomínio de grãos como uma novidade organizacional da agricultura familiar, verificando quais os resultados gerados nas famílias envolvidas. Neste sentido, o trabalho averiguou os efeitos da novidade organizacional nas condições econômicas dessas famílias, no processo de sucessão geracional e nos formatos associativos assumidos entre os membros familiares envolvidos nesse processo social.

A metodologia do trabalho consistiu numa conjugação de métodos qualitativos e quantitativos, utilizando-se de entrevista semiestruturada grupal e banco de dados acerca da renda econômica das famílias nos anos 2005, 2010 e 2015. A pesquisa foi realizada no Município de Itapejara d'Oeste, na Região Sudoeste do Paraná. Teoricamente, a pesquisa apoiou-se na Perspectiva Multinível e Co-Evolucionária (PMN), especialmente na noção de novidades no desenvolvimento rural e regional.

A noção de novidades pode ser definida como as novas práticas que os atores sociais constroem proativamente, de forma a resolver seus problemas corriqueiros (LONG, 2006). No caso dos processos de desenvolvimento rural e regional, as novidades podem ser novos conhecimentos, organizações sociais, processos produtivos e produtos, construção de novos 
mercados, formação de uma cooperativa, associação ou rede social, redefinição no uso de fatores de produção, desenvolvimento de uma agricultura mais econômica, entre outros exemplos que definiriam esse conjunto de históricas práticas inventivas que os camponeses e agricultores familiares desenvolvem ao longo dos tempos (PLOEG et al., 2004; OOSTINDIE; BROKUISEN, 2008). Neste trabalho, a experiência do condomínio de grãos é entendida como uma novidade organizacional da agricultura familiar, pois encerra novos formatos organizativos e de administração dos fatores de produção entre duas famílias com parentesco direto.

O texto está subdividido em quatro seções além desta introdução e das considerações finais. Na primeira, explica-se como o caso do condomínio foi descoberto dentro do 'projeto de pesquisa Itapejara'. Na segunda, elenca-se a metodologia da investigação. Na terceira, são referenciados os elementos teóricos da PMN e a noção de novidades. Na quarta, analisa-se o surgimento da iniciativa familiar do condomínio de grãos como uma novidade organizacional e discutem-se os principais resultados gerados para as famílias envolvidas.

\section{A descoberta do caso no 'Projeto Itapejara'}

A família em questão está inserida num projeto de pesquisa realizado no Município de Itapejara d’Oeste, Região Sudoeste do Paraná (Figura 1). Nesse caso, procurou-se investigar a fundo a trajetória de vida de uma das 100 famílias rurais de um conjunto do município, as quais são acompanhadas numa pesquisa em painel quinquenal, que acontece desde 2005 e, depois, atualizado em 2010 e 2015.

A partir da investigação de Perondi (2007; 2013), foi possível gerar um banco de dados contabilizando 100 agricultores familiares. Nesse banco de dados, a renda é considerada um dos principais indicativos socioeconômicos das famílias em foco. Para tal, o cálculo da renda dessas famílias foi obtido a partir da metodologia descrita em Lima et al. (1995) e FAO/INCRA (1999).

Nos últimos anos, algumas publicações foram realizadas com este banco de dados, como Kiyota e Perondi (2014), Coletti e Perondi (2015) e Villwock e Perondi (2016). Pesquisas como essas representam a realidade da agricultura familiar do município de Itapejara 
d'Oeste, mas, também, servem para ilustrar o contexto da Região Sudoeste do Paraná e do Sul do Brasil.

Figura 1 - Localização geográfica do município de Itapejara d'Oeste - PR

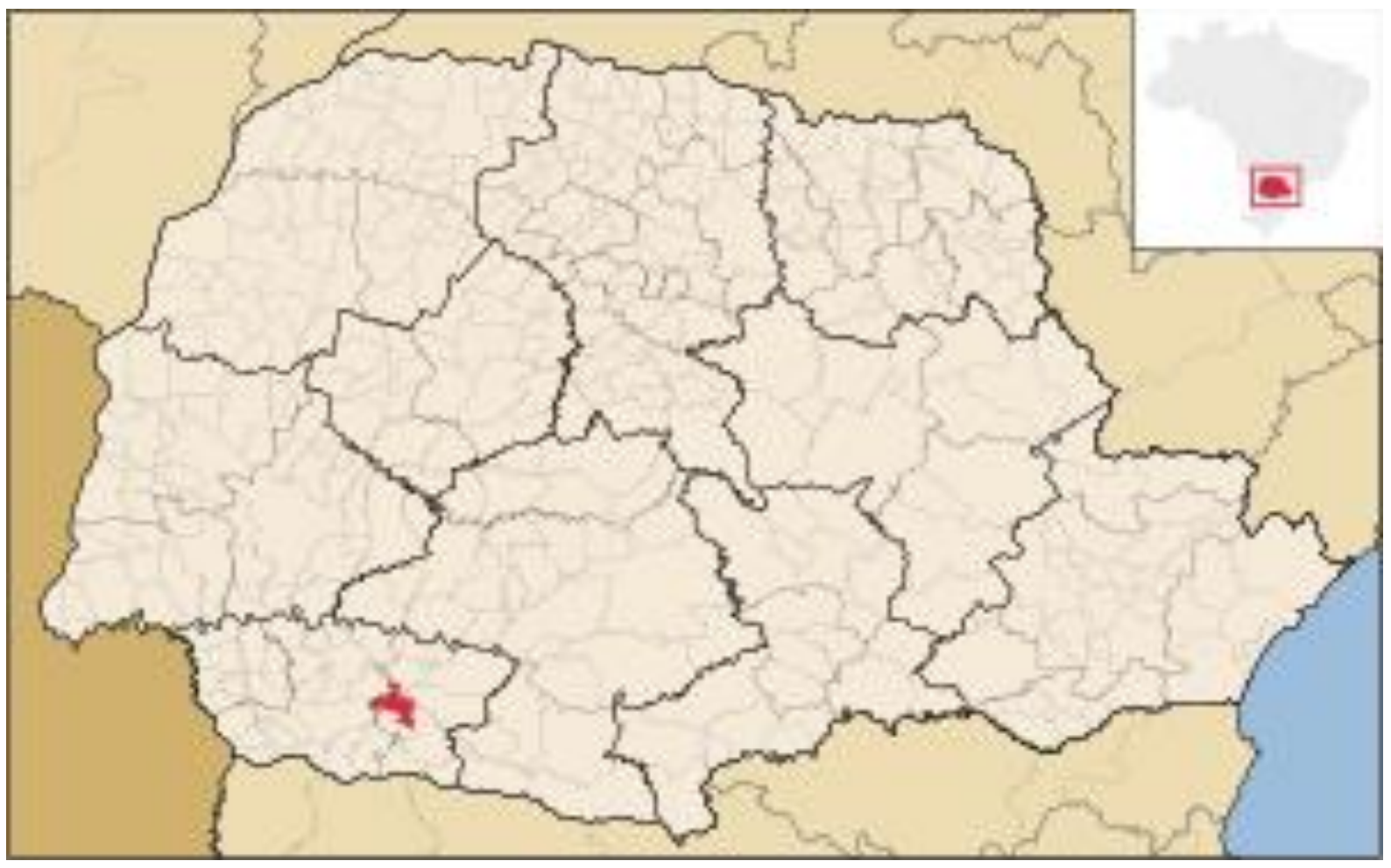

Fonte: IBGE (2014).

O município de Itapejara d'Oeste possui cerca de 11.685 habitantes, sendo $46 \%$ da população rural. Está situado a $360 \mathrm{~km}$ da capital, Curitiba, e localizado na região Sudoeste paranaense (IBGE, 2014). A escolha do município para execução do projeto deve-se ao fato desse município caracterizar e representar as "[...] particularidades socioeconômicas e agrícolas da região Sudoeste do Paraná, como a distribuição fundiária, origem étnica dos agricultores, predominância da agricultura familiar, topografia, solo e a produção de soja, milho, leite, aves e suínos" (PERONDI et al., 2015). Esse caso em particular apresentou uma impressionante recuperação da renda, entre 2010 e 2015, via a constituição de um condomínio.

\section{Metodologia da investigação}

Além da pesquisa em um referencial teórico da PMN e sobre a noção de novidades no desenvolvimento rural e regional, esta pesquisa também acompanhou a trajetória de 
renda de uma família. O diagnóstico da renda dessa família expressa um balanço dos anos agrícolas 2004/2005, 2009/2010 e 2014/2015. A pesquisa buscou, no banco de dados desses levantamentos, os seguintes indicadores econômicos apresentados no Quadro 1 a seguir.

Quadro 1 - Indicadores utilizados para fins de cálculo dos custos de produção e renda da família

\begin{tabular}{|l|l|}
\hline \multicolumn{1}{|c|}{ Indicador } & \multicolumn{1}{|c|}{ Descrição } \\
\hline PB (Produto Bruto) & $\begin{array}{l}\text { Valor de toda produção vendida, estocada e consumida pela família, no } \\
\text { período analisado, na propriedade. }\end{array}$ \\
\hline $\begin{array}{l}\text { Cl (Consumo } \\
\text { Intermediário) }\end{array}$ & $\begin{array}{l}\text { Valor dos insumos e serviços adquiridos fora da propriedade e utilizados } \\
\text { na transformação da produção. Estes insumos são totalmente } \\
\text { consumidos no processo produtivo. }\end{array}$ \\
\hline D (Depreciação) & $\begin{array}{l}\text { Valor que corresponde ao desgaste dos meios de produção que existem } \\
\text { no estabelecimento, mas que não são consumidos totalmente no } \\
\text { processo produtivo. }\end{array}$ \\
\hline $\begin{array}{l}\text { DVA (Divisão do Valor } \\
\text { Agregado) }\end{array}$ & $\begin{array}{l}\text { Despesas para manter a propriedade e que não podem ser descontadas } \\
\text { de um único sistema produtivo, tais como arrendamento, impostos, juros } \\
\text { e salários. }\end{array}$ \\
\hline RA (Renda Agrícola) & $\begin{array}{l}\text { Resultado da subtração do Cl, D, DVA do PB, ou seja, a parte líquida do } \\
\text { PB. }\end{array}$ \\
\hline $\begin{array}{l}\text { RTS (Renda de } \\
\text { Transferências Sociais) }\end{array}$ & Aposentadorias, pensões e transferências. \\
\hline $\begin{array}{l}\text { ROF (Renda de Outras } \\
\text { Fontes) }\end{array}$ & $\begin{array}{l}\text { Cobrança de arrendamentos de terras, aluguéis, rendas com poupança, } \\
\text { doações e aplicações. Rendas não oriundas do trabalho. }\end{array}$ \\
\hline $\begin{array}{l}\text { ORT (Outras Rendas } \\
\text { do Trabalho) }\end{array}$ & Atividades agrícolas fora da propriedade. \\
\hline $\begin{array}{l}\text { RNA (Renda Não } \\
\text { agrícola) }\end{array}$ & Renda de atividades não-agrícolas. \\
\hline
\end{tabular}

Fonte: Villwock (2016).

Com o intuito de avaliar a percepção do pesquisador sobre o contexto social de um condomínio produtivo, a pesquisa contou com um pré-teste do seu roteiro de perguntas em outro condomínio conhecido. Esse pré-teste permitiu melhorar o conhecimento e a sensibilidade do pesquisador acerca do tema da pesquisa.

Por fim, a última etapa desta pesquisa consistiu em estabelecer o estudo de caso, aproximando-se da família e realizando a pesquisa de campo, no condomínio, com os principais envolvidos, que se dispuseram responder a uma entrevista semiestruturada, que resgatou a história de vida desse grupo familiar e, ao mesmo tempo, esclareceu suas estratégias produtivas, sociais e inovadoras em torno do condomínio. Neste momento derradeiro da pesquisa, participaram os seguintes membros do condomínio: os dois irmãos 
(com os pseudônimos de José e Antônio), a nora e o neto de José; a esposa e um dos filhos de Antônio. Os demais estavam envolvidos em afazeres que os distanciaram da entrevista.

Por fim, é importante salientar que os valores monetários dos anos agrícolas 2004/2005 e 2009/2010 foram atualizados a partir da série do Índice Nacional de Preços ao Consumidor (INPC), disponível no site do IBGE, sendo que o índice encontrado para julho de 2005 foi de 1,761282, e, para julho de 2010, foi de 1,3974851. Para a análise da trajetória da renda dessa família, todas as variáveis monetárias que compõem a renda foram corrigidas.

\section{A noção de novidades no desenvolvimento rural e regional}

Esta seção tem o papel de apoiar teoricamente o estudo sobre a experiência do condomínio de grãos a partir do aporte da Perspectiva Multinível e Co-Evolucionária (PMN), e, dentro desta, especialmente a noção de novidades. Segundo Geels (2004), a PMN possui base em duas grandes áreas de estudos teóricos. De um lado, a Sociologia da Tecnologia, e, de outro, a Economia Evolucionária. Os primeiros trabalhos referências são dos economistas evolucionários como Kemp, Schot e Hoogma (1998), Geels (2004) e Nelson e Winter (2005), entre outros, que inauguraram a noção de regime sociotécnico. Este enfoque foi desenvolvido visando compreender os processos sociotécnicos nas firmas e indústrias, chegando até os setores intensivos em tecnologia. Ele é adaptado por Wiskerke e Ploeg (2004) e outros autores para as investigações dos processos tecnológicos e inovativos no desenvolvimento rural e regional. Com estes últimos, a abordagem incorpora os aspectos de agência dos agricultores, e há a formulação da noção de novidades.

A ideia da produção de novidades tem como principal característica diferenciar-se da noção de inovação (tecnológica), muito presente a partir dos anos de 1970 no Brasil, em função da Teoria da Modernização. Como formularam Ploeg et al. (2004), novidades e inovações possuem "histórias de vida" diferentes. Na modernização, as inovações definiramse exclusivamente como sinônimo de tecnologia e foram difundidas de modo linear, conforme eram geradas pelo conhecimento científico em centros de pesquisa e investigação, e, posteriormente, difundidas pelos serviços de assistência técnica e extensão rural, chegando até os agricultores, que as absorviam pelos mercados sob a forma de "pacotes tecnológicos" (PLOEG et al., 2004). Segundo os autores, (2004), as novidades constituiriam as 
"sementes da transição", pois, por meio delas, seria possível transições do padrão de agricultura existente para um mais sustentável, dentro dos princípios do desenvolvimento rural e regional. As novidades surgiriam nos nichos, que seriam seus espaços protegidos e incubadores, onde elas desenvolver-se-iam, permanecendo nos nichos através do tempo, ganhando o regime sociotécnico, modificando-o ou incrementando-o $0^{4}$. Os nichos estariam posicionados em um nível micro, nos quais se encontram os atores individuais, como agricultores, as tecnologias e as práticas agrícolas. É no nível do nicho que o surgimento das novidades ocorre, e são neles (nos nichos) que as novidades realizam os "desvios de rota", e as novas práticas emergem.

Também é nos nichos que os processos de conhecimento contextual são desenvolvidos pelos agricultores em interação constante com os outros atores sociais (extensionistas, pesquisadores, universidades, agências do Estado, consumidores, ambientalistas). Para Roep e Wiskerke (2004), três características são centrais para o sucesso do desenvolvimento nos nichos: (a) o desenvolvimento e alinhamento das estratégias e expectativas futuras dos atores; (b) a existência de um processo de aprendizagem social; e (c) a criação e estabilização das redes sociais existentes.

Há outras duas dimensões para a noção de novidades nos processos de desenvolvimento rural e regional. Algumas novidades produzidas pelos agricultores ocorrem internamente às unidades produtivas; já outras se desenvolvem para além destas, ganhando o contexto institucional. No primeiro caso, as principais novidades que os agricultores geram relacionam-se à prestação de um novo serviço rural, ao desenvolvimento de um novo processo produtivo ou produto. Também pode ser a invenção de uma nova tecnologia autóctone, com base em seus próprios conhecimentos e recursos.

As práticas dos agricultores também poderiam criar redes de relações entre unidades produtivas, sendo que as novidades, nesses casos, seriam as redes sociais e técnicas que os agricultores formam entre si e com outros atores, como demonstram os estudos de Marques (2009), no setor de plantas medicinais e aromáticas, e de Gazolla (2012) nas agroindústrias familiares. O condomínio de grãos ora investigado encaixar-se-ia nesse caso das novidades

\footnotetext{
4 A noção de regime sociotécnico é definida como um conjunto de práticas, tecnologias, regras e a institucionalidade vigente. No regime, estão as normas, as crenças e os interesses que servem de guia para os atores privados e a ação política. O regime é um sistema de regras e a gramática que coordena as redes de atores e coisas (artefatos, tecnologias, base material) (MOORS; WISKERKE, 2004).
} 
internas, pois os atores familiares unem-se coletivamente para a geração de uma novidade organizacional entre famílias.

No segundo caso, quando as novidades ganham os espaços institucionais, geralmente estes se caracterizam como novos mercados que foram construídos pelos agricultores para seus produtos e alimentos; em muitos casos, são cadeias curtas de comercialização, vendas coletivas, comércios em redes, novas entidades sociais com formatos organizacionais inovadores, voltadas à comercialização dos produtos. Nessas novidades externas, as propriedades podem também ser novas organizações sociais, como é o caso da constituição de associações, cooperativas, grupos comunitários, redes coletivas de agricultores, como demonstraram Ploeg et al. (2004).

A noção de novidades também se diferencia das inovações por três característicaschave. As novidades são contextualizadas, internalizadas e territorializadas (Figura 2). A contextualização refere-se à forma como os agricultores obtêm os conhecimentos para gerar as novidades. Eles se utilizam dos conhecimentos contextuais, que são conhecimentos apreendidos a partir dos contextos socioeconômico e institucional e dos repertórios culturais em que os agricultores estão inseridos. De um ponto de vista teórico, os conhecimentos contextuais são o resultado de "fusões de conhecimentos" e "mundos" dos agricultores (o chamado conhecimento tácito) com os de outros atores sociais, pesquisadores, extensionistas, agências do Estado, consumidores, agentes de desenvolvimento, ambientalistas, que se utilizam de conhecimentos científicos, educação formal e outros conhecimentos (STUIVER; WISKERKE, 2004; STUIVER, 2008).

\section{Figura 2 - Principais diferenças entre inovações e novidades}

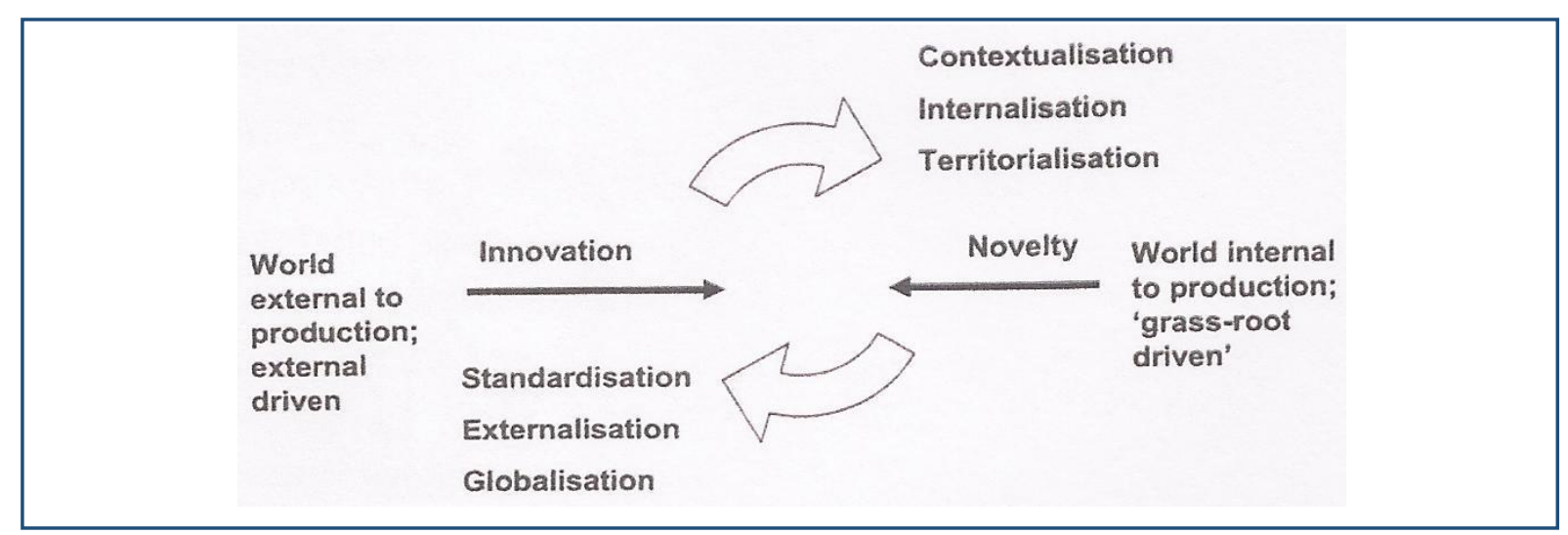

Fonte: Oostindie e Broekhuizen (2008). 
A internalização das novidades é o processo pelo qual elas são criadas, com recursos internos ao local ou até à unidade de produção agrícola - a chamada endogenidade das práticas. É, por exemplo, o que acontece na chamada agricultura econômica, como no caso da agroecologia, que é desenvolvida com recursos dos agricultores e poucas tecnologias e insumos externos à propriedade. Isso faz com que essas novidades sejam mais rentáveis e sustentáveis, pois elas conseguem, por meio de rearranjos de recursos, sintonia nos fatores produtivos e nas práticas dos agricultores, baixar custos de produção na agricultura (OOSTINDIE; BROEKHUIZEN, 2008). No caso estudado, o do condômino de grãos, é notória a mudança de comportamento frente à nova prática organizativa social das famílias.

Já a territorialização envolve a ideia de que as novidades nascem inseridas (embeddedness) em um espaço social, num conjunto de relações locais e redes de atores. 0 processo de surgimento das novidades é sempre localizado e dependente do tempo, dos ecossistemas e dos repertórios culturais em que o processo de trabalho na agricultura está imerso. Além disso, as novidades são o resultado do processo de coprodução, que é a interação e transformação do social com o natural, que se desenvolve no local ou no territorial (PLOEG et al., 2004).

As novidades também realizam um rompimento em relação à gramática do regime existente. As novidades são "desvios da rota" hegemônica e constituiriam as "sementes da transição", no sentido conotativo que lhes é dado por Ploeg et al. (2004). As novidades são consideradas radicais por (a) romperem com as regras e trajetórias tecnológicas dominantes na agricultura; (b) serem geradas fora dos padrões lineares de produção dos conhecimentos e tecnologias; e (c) carregarem consigo o potencial de gerar mudanças amplas e multidimensionais, não mensuráveis em diferentes domínios das atividades produtivas, técnicas e sociais.

Quanto à realização de investigações, do ponto de vista prático, as novidades identificadas nas experiências de desenvolvimento rural e regional podem ser agrupadas em diferentes tipos, para melhor compreender como cada uma surge, como se desenvolve, bem como os resultados que gera nas famílias, na economia local ou no ambiente institucional. Essa operação é central, para demonstrar que existem vários tipos de novidades, como, por exemplo, novos mercados, produtos, métodos de processamento de alimentos, tecnologias, novas organizações, redes sociais, entre outras práticas criativas que os agricultores 
desenvolvem. Do ponto de vista da aplicação prática da noção de novidades, no caso estudado do condomínio de grãos, esta será 'classificada' como uma novidade organizacional e coletiva entre famílias de agricultores familiares e uma nova forma de administração dos fatores existentes de produção (terra, máquinas, equipamentos e força de trabalho).

\section{0 surgimento da novidade organizacional e os resultados gerados}

5.1 Histórico da família e surgimento do condomínio

Os pais de José e Antônio (patriarcas deste condomínio) saíram do Rio Grande do Sul para desbravar as primeiras terras da região Oeste de Santa Catarina. A família se instalou no município de São Lourenço do Oeste, onde permaneceram por aproximadamente 20 anos. No ano de 1975, mudaram-se para o município de Itapejara d'Oeste, onde começaram a limpar as primeiras áreas de terra para cultivo, como relataram na entrevista: "Vai fazer 41 anos que estamos morando aqui, neste mesmo lugar" (Entrevista, Itapejara d'Oeste, 2016).

Os irmãos relataram que, antes de iniciar a atividade em associação, vinham trabalhando com a produção de grãos de forma individual e que já existia um caso de sociedade na família. O patriarca da família dividiu a terra com os filhos, dando a devida quota-parte para cada um. O filho mais velho foi o primeiro a se separar dos demais. Os irmãos mais novos trabalharam em sociedade com o pai durante anos e, aos poucos, também foram se dividindo (foram se desmembrando, trabalhando por conta própria).

Em 2010, as dificuldades financeiras que ambos os irmãos enfrentaram de forma individual deu motivos para a consolidação de uma sociedade voluntária. Com a divisão do patrimônio, os irmãos mais novos foram comprando áreas de terra mais afastadas e, com isso, foram indo para longe. José e Antônio permaneceram com áreas de terra próximas espacialmente, fazendo divisa, e esse foi um dos principais fatores que influenciaram no surgimento do condomínio.

A sociedade dos irmãos José e Antônio teve início por ocasião da compra de um terreno próximo do Rio Chopim, no ano de 2010. Um senhor tinha intenção de vender uma pequena área de terra ali próxima, que foi ofertada para José. Naquela época, José disse que não teria condições de realizar a compra sozinho. O dono do terreno insistiu na proposta de 
venda. José, então, lembrou do irmão e pensou que, em dois, seria possível realizar a compra da terra, que tinha em torno de seis alqueires. Os irmãos fizeram a parceria para a aquisição da área, pois entenderam que poderiam assumir a dívida juntos, como confirma o relato: “Conversamos e tal, mas entre os dois dá de nós comprar! E daí, naquele dia mesmo, fizemos o negócio da terra" (Entrevista, Itapejara d'Oeste, 2016).

A atividade que desempenhavam antes do condomínio já era com grãos, o que veio a reforçar a cooperação entre ambos na atividade conjugada e trabalhando coletivamente. $\mathrm{Na}$ entrevista, quando perguntados sobre quem idealizou, ou tomou a iniciativa da associação, e o que os levou a fazer essa escolha, responderam, conforme relato abaixo, que foi uma decisão em conjunto, das duas partes das famílias:

\footnotetext{
Acho que as duas partes deu tão certo que, quando um pensou, o outro já falou" (risos) [...] a gente viu a necessidade de se unir pra poder comprar as coisas, que individual ninguém podia ter tudo que precisa, e daí se unimos pra trabalhar na agricultura. E o pai gostava de ver os filhos unidos... então a gente veio naquela união da família, né (Entrevista, Itapejara d’Oeste, 2016).
}

5.2 A trajetória da renda

A seguir, serão apresentados os dados que contêm a composição do produto bruto e a composição da renda total da família nos anos agrícolas 2004/2005, 2009/2010 e 2014/2015. Para contextualização do cenário agrícola, é importante ressaltar que, no ano de 2005, os agricultores da região Sudoeste do Paraná enfrentaram uma estiagem que influenciou de forma direta a agricultura, fazendo com que houvesse uma abrupta queda na renda rural.

Via o banco de dados do Projeto Itapejara, foi possível observar um grande número de famílias que teve renda total negativa como consequência dessa estiagem, sendo que a família em questão, apresentada na Figura 3, teve uma renda agrícola negativa de $\mathrm{R} \$$ 100.437,93. Nesta safra, o que 'salvou' a família monetariamente foi o refinanciamento agrícola promovido pelo Governo Federal. 
Figura 3 - Indicadores da composição do produto bruto (A) e da renda total (B) no ano agrícola 2004/2005

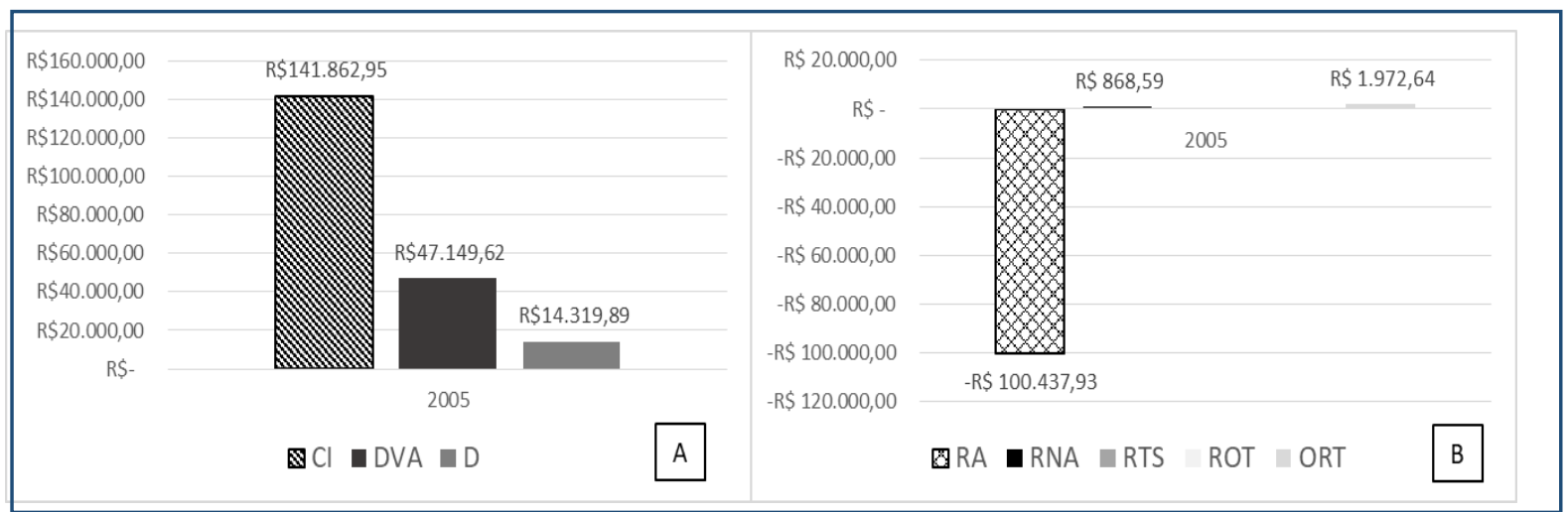

Fonte: Elaborado pelos autores a partir de Perondi (2007).

No ano anterior (2004), a família tinha obtido um bom resultado na safra de soja e, por isso, estava confiante para realizar novos investimentos, adquirindo, então, trator e equipamentos novos - financiados por um prazo de 7 anos. Em 2005, além dos prejuízos da safra, os preços dos insumos agrícolas estavam elevados, e ainda havia a parcela do financiamento para pagar, além, é claro, do custeio das lavouras daquele ano, conforme o relato a seguir: "Pra nós é tão, assim, a gente não esquece na certa disso aí. Porque nós tínhamos comprado os tratores em 2004 pra pagar em 2005 e cadê o tal de soja?" (Entrevista, Itapejara d'Oeste, 2016).

Para tentar contornar as dívidas, o produtor conseguiu refinanciar o custeio da safra para mais cinco anos. Mesmo assim, a renda agrícola, que era a principal receita da família, ficou negativa para o ano de 2005 , conforme mostra o relato da entrevista:

\footnotetext{
Então nós, não vamos esquecer disso aí nunca, né? Só que veio a negociação do trator automático lá no Banco do Brasil, veio todas as negociações, foi pagado as dívidas particulares, e, em banco negociado, prolongado que foi até 2014 ... fizeram pra 8 anos, daí deu duas secas a fio, foi pra 10 anos daí, todo ano jogava pra frente, vamos dizer assim, aqueles financiamentos até foram bom, não tinha PROAGRO, não tinha... mas daí, assim, o custeio eles prolongaram em 5 anos, e máquina financiada era depois da última mais uma (Entrevista, Itapejara d’Oeste, 2016).
}

É válido ressaltar que, além da produção de grãos, naquela época, a família possuía um pequeno rebanho de gado leiteiro, sendo que a renda advinda da produção do leite foi o que permitiu a sobrevivência financeira da família, quando perdeu a safra de soja com a estiagem de verão. O leite é um componente da renda agrícola, e, nesse sentido, a renda do leite (que era um projeto das mulheres e não tinha o apoio dos homens) foi o que tornou o 
faturamento menos negativo, além, é claro, das reservas que a família possuía e que foram mobilizadas para que pudessem manter-se naquele período. Por isso, a atividade do leite, bem como a atuação das mulheres, deve ser valorizada, pois, para essa família, assim como para tantas outras da região Sudoeste do Paraná, naquele ano, o leite foi importante para a sobrevivência da agricultura familiar.

Historicamente, o leite se faz muito presente na agricultora familiar da região Sudoeste do Paraná, seja pela forte presença dos traços culturais que envolvem a atividade, ou mesmo porque o leite é uma garantia em situações de adversidades. A cadeia produtiva do leite é a mais importante e abrangente para a agricultura familiar na região Sudoeste, que é considerada a maior bacia leiteira do estado do Paraná.

Diferentemente do ocorrido em 2005, no ano de 2010, os resultados da safra foram favorecidos pela distribuição normal de chuvas, o que proporcionou boas safra e colheita, além de estabilidade dos mercados e bons preços agrícolas, ocasionando boas vendas ao final da safra. Foi possível observar que a renda agrícola no ano de 2010 fechou com um saldo positivo de $\mathrm{R} \$$ 44.501,48, conforme apresentado na Figura 4, levando-se em consideração que a família ainda estava se recuperando das frustrantes safras dos anos anteriores. Além disso, a família possuiu, neste ano, renda de transferências sociais de $\mathrm{R} \$$ $9.265,33$, além de outras rendas de trabalho no valor de $\mathrm{R} \$ 2.096,23$, que complementaram a renda total.

Figura 4 - Indicadores da composição do produto bruto (A) e da renda total (B) no ano agrícola 2009/2010

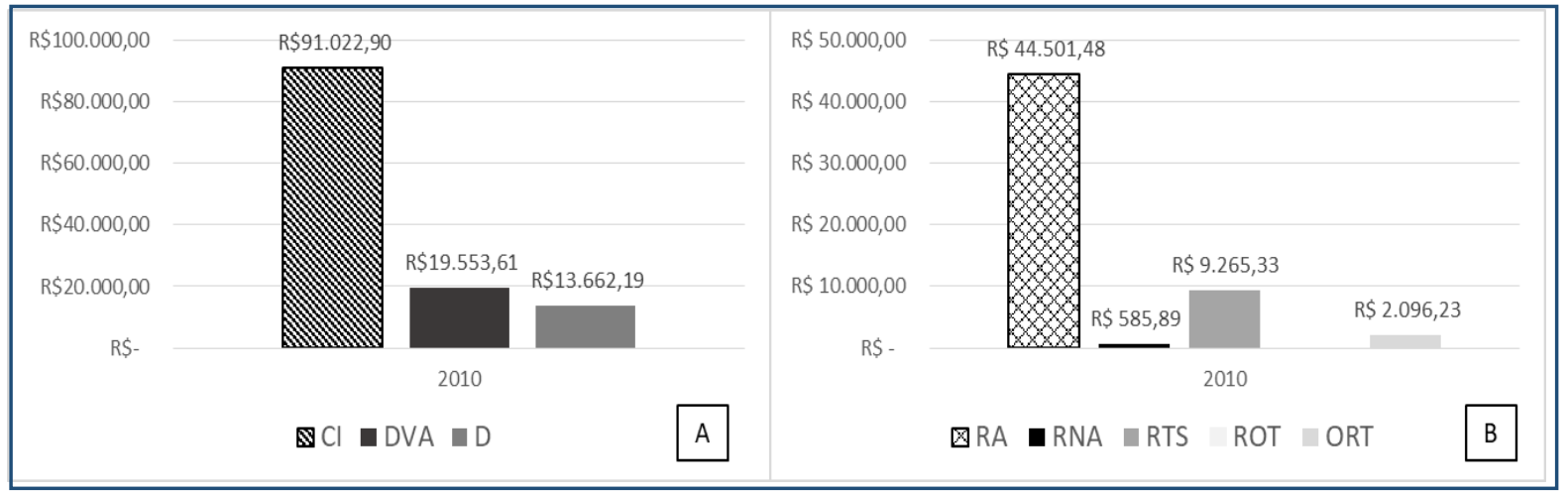

Fonte: Elaborado pelos autores a partir de Perondi (2013). 
Para o ano de 2015 (quando a experiência do condomínio já existia há 5 anos), foi possível observar um crescimento considerável da renda agrícola da família, que saltou para o valor de $\mathrm{R} \$ 258.056,20$ (Figura 5), e isso pode ser explicado porque a família passou a exercer a sua forma de trabalho em condomínio rural; o trabalho em associação permitiu maior racionalização no uso dos fatores de produção - maximização dos fatores terra, capital e trabalho. $O$ efeito disso reflete diretamente no aumento de renda da família, e pode-se dizer que esse fator positivo somente foi proporcionado à família porque houve a opção pelo condomínio.

Além de aumento da renda agrícola, nessa safra, ocorreu elevação das demais rendas, por exemplo, a renda de transferências sociais foi de $\mathrm{R} \$ 20.488,00$; a renda de outros trabalhos foi de $\mathrm{R} \$ 18.000,00$; e a renda não agrícola, de $\mathrm{R} \$ 4.500,00$, evidenciando aumento expressivo de renda, muito além daquela proveniente da agropecuária.

Figura 5 - Indicadores da composição do produto bruto (A) e da renda total (B) no ano agrícola 2014/2015

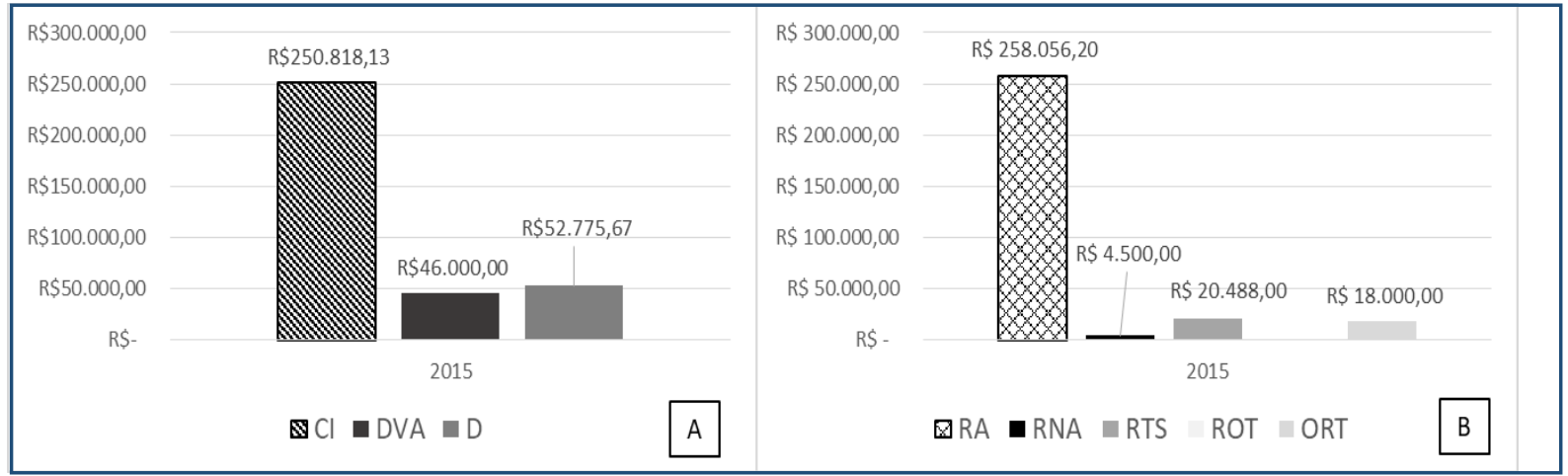

Fonte: Pesquisa de campo (2016).

Esse crescimento da renda da família ao longo dos anos, atrelado ao desenvolvimento do condomínio, pode ser visualizado de maneira clara nas Figuras 6 e 7, que trazem a comparação da composição da renda total e do produto bruto nos anos 2005, 2010 e 2015. Na Figura 6, nota-se uma redução dos custos produtivos totais da iniciativa, passando de R\$ 203.332,46, no ano de 2005, para R\$ 124.238,70 em 2010. No ano de 2015, há novamente aumento dos custos produtivos totais, ficando na ordem de $\mathrm{R} \$ 349.593,80$. 
Figura 6 - Gráfico comparativo da composição do produto bruto da família do estudo de caso nos anos 2005, 2010 e 2015

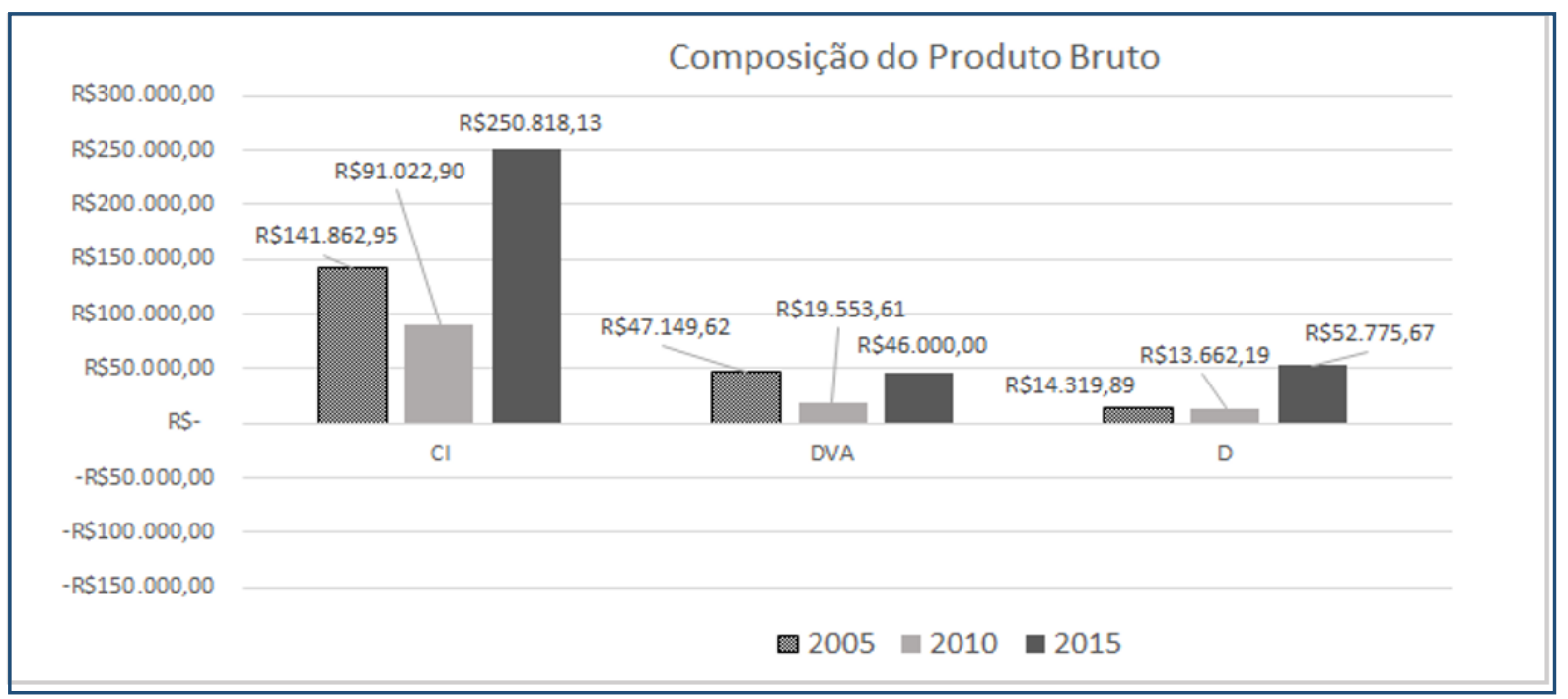

Fonte: Pesquisa de campo (2016).

A Figura 7 mostra a evolução da composição da renda total da iniciativa do condomínio de grãos, evidenciando que, mesmo que os custos totais produtivos tenham aumentado, no ano de 2015, a renda gerada compensou sobremaneira a elevação de custos, já que, nesse ano, ela é de $\mathrm{R} \$ 258.056,20$.

Quando se analisa a renda total por ano, é possível perceber a sua evolução e aumento. No ano de 2005, essa renda ficou em - R\$ 100.437,93; portanto, negativa, havendo prejuízo na família. No ano de 2010, há uma recuperação muito significativa, perfazendo R\$ $56.448,93$, elevando-se ainda mais no ano de 2015, atingindo o patamar de $\mathrm{R} \$ 301.044,20$.

Estes dados evidenciam o grande aumento da renda total que a experiência do condomínio gerou para as famílias envolvidas. 
Figura 7 - Gráfico comparativo da composição da renda total da família do estudo de caso nos anos 2005, 2010 e 2015

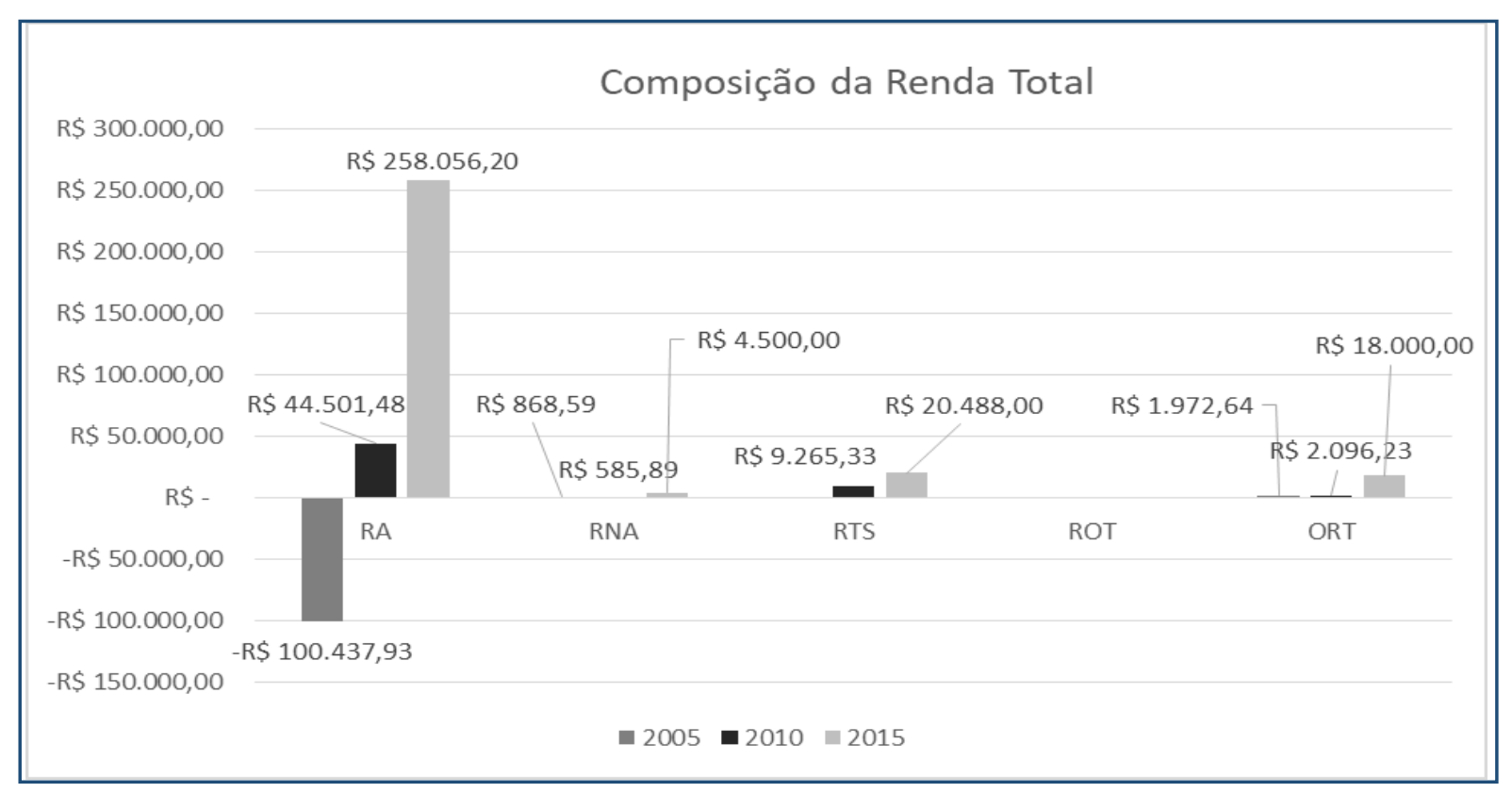

Fonte: Pesquisa de campo (2016).

Nas Figuras 8 e 9, na sequência, comparou-se a renda agrícola e o total da iniciativa em condomínio da família com as demais famílias pesquisadas no município, ao longo das três séries históricas anuais. Especificamente, em relação à Figura 8 , nota-se que, no ano de 2005, a família possui renda agrícola de $-\mathrm{R} \$ 100.437,93$, enquanto a média das famílias do município de Itapejara d’Oeste era de $\mathrm{R} \$$ 9.437,64, maior, portanto, do que a da experiência analisada. No ano de 2010, as rendas agrícolas quase se equivalem, diferindo em torno de mil reais, e, no ano de 2015, a renda agrícola da família ( $R \$ 258.056,20)$, já em condomínio, é mais de três vezes maior que a média do município ( $R \$ 73.537,85)$, evidenciando a potencialidade da sociedade condominial em auferir rendas maiores. 
Figura 8 - Comparação da renda agrícola da família com a média do município para os anos 2005, 2010 e 2015

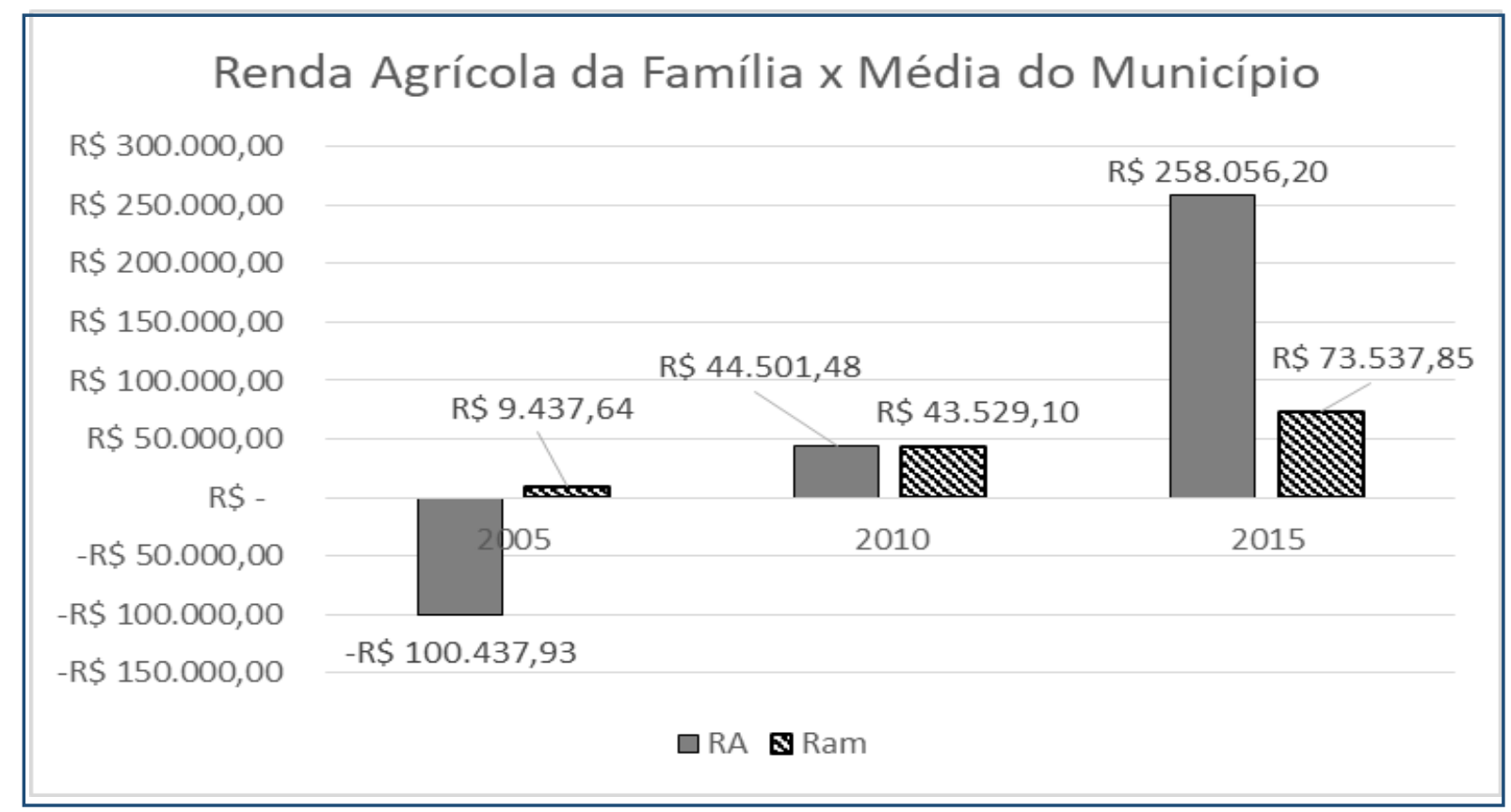

Fonte: Pesquisa de campo (2016).

Já a Figura 9 apresenta a renda total da família investigada em relação à média das demais famílias do município nos três anos pesquisados. No ano de 2005, a renda total familiar é de - $\mathrm{R} \$ 98.465,29$, e a média das demais famílias, $\mathrm{R} \$ 30.109,60$, evidenciando, nas demais famílias do município, renda total maior. No ano de 2010, essa situação ainda persiste; porém, a diferença já é bem menor, em torno de apenas 12 mil reais a mais para as demais famílias municipais. Em 2015, após a criação do condomínio, a família possui renda total de R\$ 296.544,20, enquanto a média das famílias do município é de apenas R\$ $118.715,45$, evidenciando uma grande diferença de renda total da família em condomínio. 
Figura 9 - Comparação da renda total da família com a média do município para os anos 2005, 2010 e 2015

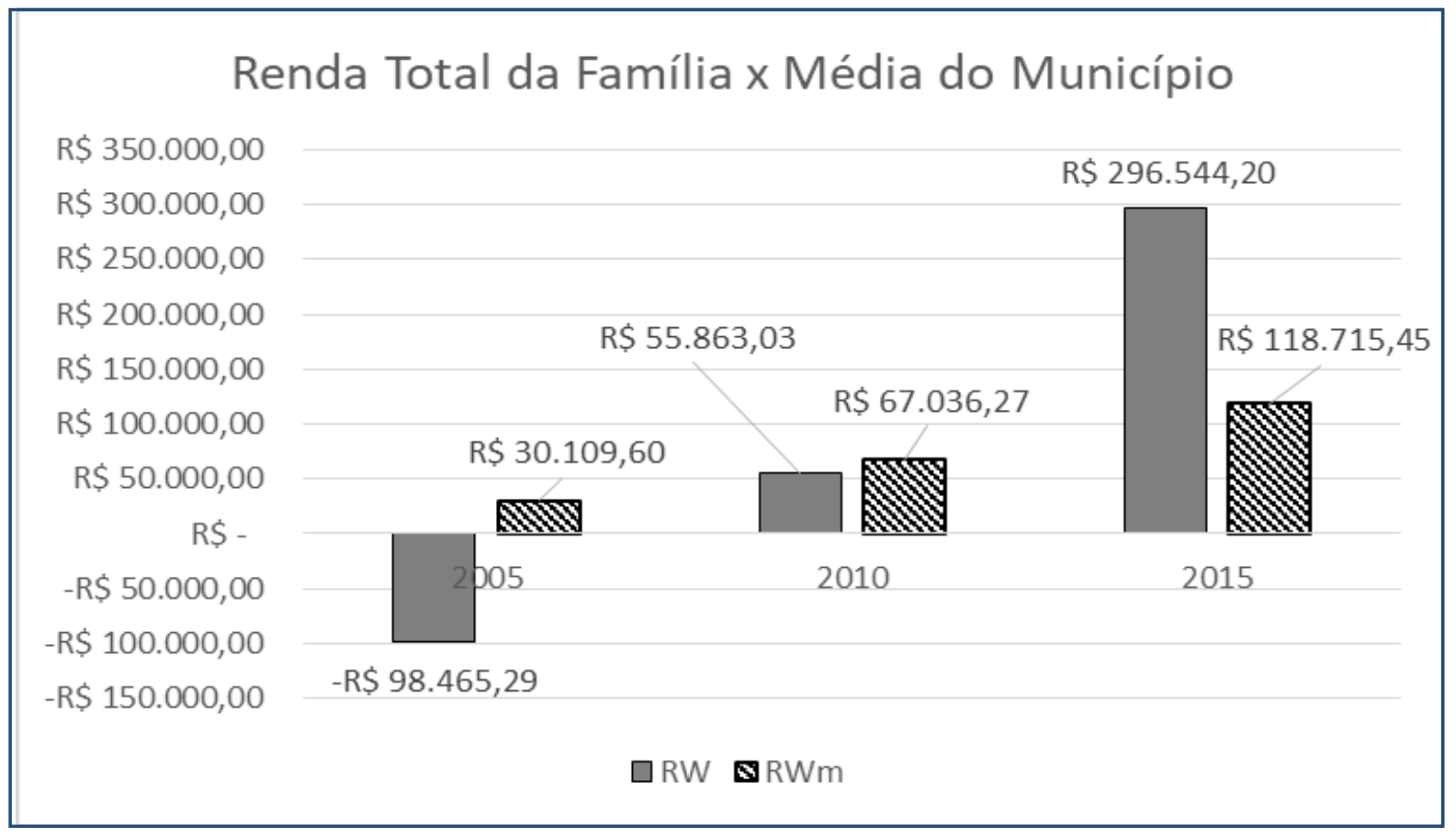

Fonte: Pesquisa de campo (2016).

Estes dados apresentados e discutidos até agora evidenciam que a criação do condomínio. em 2010, enquanto uma novidade organizacional entre as famílias, gerou melhorias, principalmente em termos de maior renda econômica disponível na propriedade rural, tanto agrícola como total. Esse processo de aumento da renda na experiência vai ao encontro do que a literatura revisada na seção quatro apresentou, ou seja, as novidades possuem efeitos multidimensionais, sendo um deles a melhoria das condições econômicas e, consequentemente, da qualidade de vida dos agricultores, já que, com estes recursos, os atores sociais podem dispor de bens e serviços de que antes não dispunham, ou fazer reinvestimentos na unidade produtiva, ou, até, optar por poupança familiar.

Reagindo criativamente na construção de uma nova forma de trabalho em conjunto, a família adaptou-se e construiu uma novidade organizacional, já que ocorreu a junção coletiva de duas famílias para desenvolverem trabalhos conjugados. Além disso, ocorreu uma mudança de trajetória de vida das duas famílias, o que as levou a uma inserção nos mercados agropecuários com uma estratégia diferenciada em relação à que vinha sendo exercida anteriormente (com uma escala mercantil um pouco maior, o que propiciou 
negociarem preços mais elevados para os grãos no momento da comercialização), gerando maior renda e qualidade de vida aos participantes. Nesse sentido, os dados comprovam que a novidade organizacional gestada pela família - que é o condomínio - proporcionou benefícios econômicos ao grupo familiar.

\subsection{Sucessão geracional e associativismo familiar}

Segundo Savian (2014), o processo de sucessão geracional na agricultura pode ser entendido como "[...] a criação de uma nova geração de indivíduos que permanecem no campo e que assumem o comando do estabelecimento agropecuário", constituindo sucessores para a unidade de produção.

A sucessão geracional é um processo social que já vem acontecendo na família analisada, em função de progenitores e sucessores trabalharem juntos, sendo os sucessores preparados para dar continuidade às atividades e assumir os negócios da família. O processo de sucessão geracional foi fortalecido com o surgimento do condomínio, pois este sedimentou ainda mais a confiança no trabalho e na ideia de que todo patrimônio construído ficará para a família. Isso ocorre devido ao aumento quantitativo e qualitativo dos recursos econômicos da experiência, que implicou diretamente sobre uma maior motivação e decisão dos jovens em permanecer na atividade ${ }^{5}$.

Quando perguntados sobre quais os motivos que os levaram a tomar essa decisão de permanecer na propriedade, os filhos de Antônio e José responderam que um dos principais motivos foi a aquisição da frota de máquinas, que melhorou o trabalho nas atividades produtivas, especialmente em relação à sobre-exploração, que diminuiu. Os investimentos em patrimônio na unidade foram fundamentais para embasar a decisão dos filhos de Antônio e José em permanecer na propriedade rural.

\footnotetext{
${ }^{5}$ Por sua vez, outros fatores também explicam a sucessão geracional que acontece no estudo de caso. Além do próprio condomínio, o contexto de bom preço e exportações das commodities agrícolas, nos últimos 10 anos, é um destes fatores. Além disso, menciona-se o forte apoio do Estado neste período, pois foram desenhadas várias políticas públicas de apoio à agricultura familiar, por exemplo, o Programa Nacional de Fortalecimento da Agricultura Familiar (PRONAF), que financiou o acesso à mecanização e tecnologias para as duas famílias. Por fim, as rendas de transferências sociais são fundamentais à reprodução social da família, especialmente nos anos de renda agrícola negativa, como em 2005, em função da estiagem.
} 
Além disso, os filhos de José e Antônio (primos e irmãos) têm uma ligação afetiva muito forte entre eles e os pais; estes laços sociais sólidos apoiam a constituição de relações familiares duradouras. Foi relatado, também, durante a entrevista, a liberdade e autonomia existentes no desenvolvimento das atividades produtivas, o que evidencia que não há relações assimétricas de poder na família, como em muitos casos relatados pela literatura, em que o pai concentra poder de decisão e gestão da unidade familiar (KIYOTA; PERONDI, 2014).

Perguntou-se, então, se os filhos dos sucessores já demonstram interesse em dar continuidade ao trabalho dos pais. José e Antônio responderam que sim, que já percebem o interesse por parte dos netos e o gosto pela atividade rural, e que este bom relacionamento advém desde o seu avô, que veio do Rio Grande do Sul, perdurando ao longo do tempo entre as gerações. Também ficou claro na fala dos atores sociais o padrão do minorato na sucessão geracional, relação social típica e histórica das famílias italianas do Sul do Brasil.

Por fim, quando questionados se depositam confiança nos filhos, José e Antônio prontamente responderam que sim, que confiam 100\%, e ainda os elogiaram: "Os três são de confiança, planejam certo, sei lá, parece que, ter certeza que não dá errado o que eles planejam" (Entrevista, Itapejara d'Oeste, 2016). Esses bons resultados auferidos ao encaminhamento da sucessão nas famílias, devido à construção da experiência do condomínio, já havia sido também retratado em outros trabalhos no PR, como é o caso do Condomínio Pizzolatto, estudado por Kyiota, Perondi e Vieira (2012).

Em resumo, a família construiu a experiência do condomínio (novidade organizacional) e, como um dos resultados, dela emergem outros fatores que corroboram o sucesso da iniciativa familiar (Figura 10). Como consequência do estabelecimento do condomínio, aumentaram as exigências em investimentos, o que proporcionou maior interesse e motivação dos filhos em permanecer na atividade. Logo, essa novidade está diretamente relacionada ao encaminhamento do processo social de sucessão geracional. 
Figura 10 - Resultados multidimensionais da novidade organizacional do condomínio de grãos

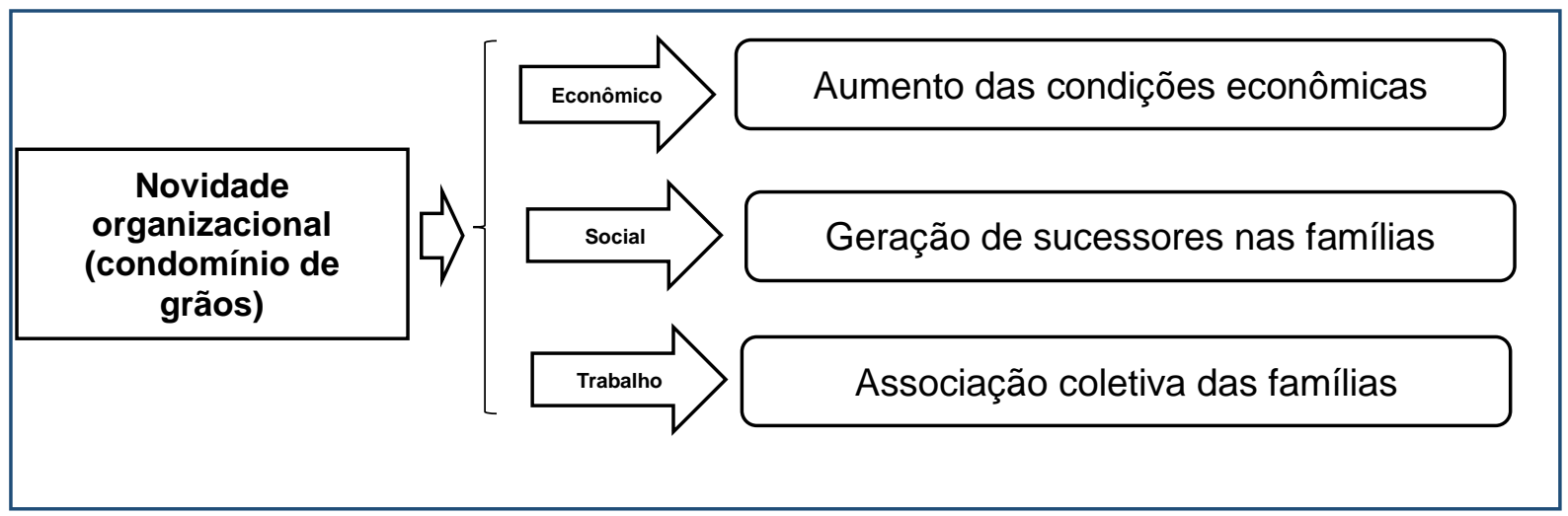

Fonte: Elaborado pelos autores (2016).

Além de aumento de renda das famílias e a sucessão geracional, outro resultado importante que surge do condomínio é o trabalho coletivo e associativo entre os membros das duas famílias (Figura 10) ${ }^{6}$. Como estudos já mostraram, em muitos casos, há, na agricultura familiar, processos de trabalho individualizados e com alto grau de divisão social do trabalho no interior da família (cada membro realiza algumas atividades específicas e tarefas especializadas) (BRUMER, 2007).

A experiência do condomínio de grãos é destoante do relatado neste parágrafo acima por dois motivos. Primeiro, porque a noção de associativismo é posta em prática pelos dois grupos domésticos. As atividades, as tarefas diárias operacionais e a gestão da iniciativa são decididas de modo coletivo pelos membros, de forma que todos possam opinar nas decisões e apoiar-se mutuamente no desenvolvimento das atividades laborais e produtivas. Segundo, embora haja certa divisão social do trabalho familiar entre os membros das duas famílias, essa divisão não é fixa nem rígida, podendo haver trocas de atividades entre os integrantes, negociações em torno delas e flexibilidade na realização dos trabalhos, pois a decisão e a gestão são realizadas de forma coletiva e associativa.

Deste modo, o condomínio de grãos também contribuiu para que os membros individuais dos dois grupos sociais familiares se aproximassem socialmente, realizando

\footnotetext{
${ }^{6}$ Segundo Alencar (1997), a noção de associativismo está relacionada à atividade humana desenvolvida em grupo. O associativismo é uma relação baseada na confiança e cooperação. Como as associações são grupos sociais, o associativismo pode se manifestar de duas formas: de natureza informal ou legalizada (formal). $O$ associativismo informal representa formas espontâneas de ajuda mútua, de modo geral, desenvolvidas entre membros de uma comunidade. O caso em análise, de um condomínio rural informal, pode ser enquadrado nesta definição do autor acima citado, porém com um caráter de laços sociais de parentesco e informais.
} 
trabalhos e gestão social conjugados e associativos, nos quais todos os processos sociais são discutidos, decididos, planejados e colocados em prática de forma que todos os atores sociais decidam pelo melhor 'projeto' e 'caminho' a seguir. Neste sentido, a novidade organizacional do condomínio também gerou como resultado um processo de associativismo rural-familiar informal, mas com fortes laços sociais entre os membros e grupos domésticos (KYIOTA; PERONDI; VIEIRA, 2012) (Figura 10).

\section{Considerações finais}

O objetivo do trabalho foi o de analisar a novidade organizacional de um condomínio de grãos vivenciada por duas famílias de agricultores no Sudoeste do Paraná. Esta pesquisa evidenciou que a produção de grãos na agricultura familiar permite o incremento da escala produtiva via a otimização das áreas de terra, máquinas e equipamentos e força de trabalho em comum.

A experiência do condomínio é, na realidade, uma novidade organizacional que gerou três grandes resultados para essas famílias: (a) aumentou a sua capacidade econômica, especialmente quando se analisam os dados de renda agrícola gerada ao longo do período pesquisado de 2005 a 2015; (b) permitiu haver condições sociais e materiais para que os jovens se sentissem parte contemplada do empreendimento familiar, comprometendo-os a seguir à frente dos processos de gestão e trabalho, permitindo que se realizasse a sucessão geracional; (c) ampliou a colaboração entre as famílias, gerando processos de gestão e de trabalho associativo, de forma que os membros familiares decidissem conjuntamente seus projetos de forma coletiva, o que permitiu reduzir o risco da produção.

Estes três resultados da geração da novidade organizacional apontam para o que a literatura afirma: de que as novidades elevam os níveis de autonomia das experiências de desenvolvimento rural regional e dos atores sociais envolvidos. Isso, ao longo do texto, foi constatado e demonstrado qualitativa e quantitativamente com os dados. Segundo a literatura revisada na seção quatro do trabalho, as novidades também possuem o potencial de aumentar os níveis de sustentabilidade ambiental nos nichos em que emergem. 
Contudo, no caso do condomínio, isso não acontece, já que a produção de grãos é realizada segundo os princípios da modernização da agricultura (uso de insumos químicos, motomecanização, OGM's, etc.). Nesse sentido e levando em conta o arcabouço teórico da PMN, pode-se dizer que, no caso em análise, a produção de novidades gera transições no regime sociotécnico (aumento de renda, sucessão e associação familiar), mas também incrementa, por seguir a trajetória dos processos modernizantes da agricultura, não contribuindo para a mudança do padrão tecnológico vigente e da sustentabilidade ambiental rural.

\section{Referências}

ALENCAR, E. Associativismo rural e participação. Lavras: UFLA/FAEPE, 1997.

BRUMER, A. A problemática dos jovens na pós-modernidade. In: CARNEIRO, Maria J.; CASTRO, Elisa G. de. (Orgs.). Juventude rural em perspectiva. Rio de Janeiro: Mauad X, 2007, p. 35-51.

COLETTI, V. D.; PERONDI, M. A. Produção de leite e resistência da agricultura familiar: comparando duas estratégias de comercialização local na região Sudoeste do Paraná - Brasil. Santa Cruz do Sul: REDES. Impresso. v. 20, p. 236, 2015.

FAO/INCRA - Organização das Nações Unidas para a Agricultura e a Alimentação / Instituto Nacional de Colonização e Reforma Agrária. Guia Metodológico "Análise Diagnóstico de Sistemas Agrários" (DSA), 1999.

GAZOLLA, M. Conhecimentos, produção de novidades e ações institucionais: cadeias curtas das agroindústrias familiares. 292f. 2012. Tese (Doutorado em Desenvolvimento Rural Programa de Pós Graduação em Desenvolvimento Rural) - Universidade Federal do Rio Grande do Sul, Porto Alegre, 2012.

GEELS, F. W. Understanding system innovations: a critical literature review and a conceptual synthesis. In: ELZEN, B.; F. W.; GREEN, K. System Innovation and the transition to sustainability. Cheltenham: Edward Elgar, 2004. p. 19-47,

GRAZIANO DA SILVA, J. Tecnologia e agricultura familiar. Porto Alegre: UFRGS, 1999.

INSTITUTO BRASILEIRO DE GEOGRAFIA E ESTATÍSTICA. IBGE cidades. 2014. Disponível em: <https://cidades.ibge.gov.br/brasil/pr/itapejara-doeste/panorama>. Acesso em: 21 nov. 2017. 
KEMP. R; SCHOT, J.; HOOGMA, H. Regime schifts to sustainably throuch processes of niche formation: the approach of strategic niche management. Technology Analysis \& Strategic Management, Abingdon, v. 10, n. 2, 21 p., 1998.

KIYOTA, N.; PERONDI, M. A. Migração e sucessão geracional na agricultura familiar sob a perspectiva de comunidade e renda. In: 52 ㅇ Congresso da SOBER, 2014 Goiânia - GO. Anais do 52 o Congresso da SOBER. 2014. v. 1 p. 1-18

Sucessão geracional na agricultura familiar: uma questão de renda? In: $O$ mundo rural no Brasil do século 21. V. 1. Brasília: Embrapa, 2014. p. 947-981.

KIYOTA, N.; PERONDI, M. A.; VIEIRA, J. A. N. Estratégia de sucessão geracional na agricultura familiar: o caso do Condomínio Pizzolatto. Informe Gepec. Toledo, v. 16, n. 1, p. 192-211, 2012.

LIMA, A. P. et al. Administração da unidade de produção familiar: modalidades de trabalho com agricultores. ljuí: Unijuí, 1995.

LONG, N. Sociologia Del Desarollo: una perspectiva centrada en el ator. Ciudad de México: Centro de Investigaciones y Estudios Superiores, 2006. (Coleción Investigaciones).

MARQUES, F. C. Velhos Conhecimentos, Novos Desenvolvimentos: Transições no Regime Sociotécnico da Agricultura. A produção de Novidades entre Agricultores Produtores de Plantas Medicinais no Sul do Brasil. 220 f. 2009. Tese (Doutorado em Desenvolvimento Rural - Programa de Pós-Graduação em Desenvolvimento Rural) - Universidade Federal do Rio Grande do Sul, Porto Alegre, 2009.

MOORS, E; WISKERKE, J. S. C. The Dinamics of Innovation: A Multilevel Co-evolucionary Perspective. In: PLOEG, J. D. van der; WISKERKE, J. S. C. (Eds.) Seeds Of transition: essays on novelty production, niches and regimes in agriculture. Wagningen: Royal Van Gorcum, 2004.

NELSON, R. R.; WINTER, S. G. Uma teoria evolucionária da mudança econômica. Campinas: Unicamp, 2005. (Clássicos da Inovação).

OOSTINDIE, H.; van BROEKHUOZEN, R. The dynamic of novelty production. In: J. D. van der Ploeg \& T. Marsden (Eds.). Unfolding webs: the dynamics of regional rural development. Assen: Van Gorgum, 2008.

PERONDI, M. A. Diversificação dos meios de vida e mercantilização da agricultura familiar. 2007. 237p. Tese (Doutorado - Programa de Pós-Graduação em Desenvolvimento Rural) Universidade Federal do Rio Grande do Sul, Porto Alegre, 2007.

. Estratégias de diversificação dos meios de vida dos agricultores familiares do município de Itapejara do Oeste (PR) 2005-2010. Edital Universal CNPq482758/2011-2 Relatório de Pesquisa, 2013. 
PERONDI, M. A. et al. As estratégias de diversificação e especialização da renda rural frente às categorias de alta e baixa renda. In: 53 C Congresso da SOBER - Sociedade Brasileira de Economia, Administração e Sociologia Rural. João Pessoa, 2015.

PLOEG, J. D. van der. El proceso de trabajo agrícola y la mercantilización. In: GUZMAN, E. S.; GONZÁLES DE MOLINA, M (Eds.). Ecología, campesinato y historia. Madri: Las ediciones de la Piqueta, 1992. p. 153-195.

PLOEG, J. D. van der. et al. On Regimes, Novelties, Niches and Co-Production. In: PLOEG, J. D. van der; WISKERKE, J. S. C. (Eds.) Seeds Of transition: essays on novelty production, niches and regimes in agriculture. Wagningen: Royal Van Gorcum, 2004. p. 1-28.

ROEP, D.; WISKERKE, J. S. C. Reflecting on Novelty Production and Niches Management in Agriculture. In: PLOEG, J. D. van der; WISKERKE, J. S. C. (Eds.) Seeds Of transition: essays on novelty production, niches and regimes in agriculture. Wagningen: Royal Van Gorcum, 2004.

SAVIAN, M. Sucessão geracional: garantindo-se renda continuaremos a ter agricultura familiar? Revista Espaço Acadêmico - 159 - mensal - agosto de 2014. p. 97-106.

SCHNEIDER, S.; CASSOL, A. Diversidade e heterogeneidade da agricultura familiar no Brasil e algumas implicações para as políticas públicas. Cadernos de Ciência \& Tecnologia. Brasília, v. 31, n. 2, p. 227-263, maio/ago. 2014.

STUIVER, M. Regime, change and storylines: a sociological analysis of manure practices in contemporary Dutch farming. Wageningen: Wagningen University, 2008.

STUIVER, M.; WISKERKE, J. S. C. The power of Experience: Farmers Knowledge and Sustainable Innovations in Agriculture. In: PLOEG, J. D. van der; WISKERKE, J. S. C. (Eds.) Seeds Of transition: essays on novelty production, niches and regimes in agriculture. Wagningen: Royal Van Gorcum, 2004.

VILLWOCK, A. P. S.; PERONDI, M. A. Análise das estratégias de renda dos agricultores familiares de Itapejara D' Oeste. (Santa Cruz do Sul : REDES (Online). v. 21, p. 215 - 238, 2016.

WISKERKE, J. S. C.; PLOEG, van der J. D. (Orgs.) Seeds of Transition: essays on Novelty production, Niches and Regimes in Agriculture. Wageningen: Royal van Gorcum, 2004. 